\title{
STUDI ANALISIS MENGENAI MAKSUD "ALLAH ADALAH TERANG" DAN HUBUNGANNYA DENGAN ORANG PERCAYA YANG MENGAKU DOSA- DOSANYA MENURUT 1 YOHANES 1:5-10
}

\author{
Farel Y. Sualang, M.Th \\ Email: sualangfarel@gmail.com \\ Sekolah Tinggi Teologi Injili Indonesia, Yogyakarta
}

\begin{abstract}
Abstrak
The Study of the Analys is of the purpose of "God is light" and its relationship to the believer who confesses the sins according to 1 John 1:5-10 will be discussed in this article by focusing on explaining the meaning of the word "darkness and light" in the life of the believer. The introduction to this letter serves to establish the personal testimony of

John describing the eternal and personal life, and the work of Jesus Christ. John also introduces several major themes discussed in this passage of the letter: life, witness, fellowship, and the relationship of the Father and Jesus Christ. Verses 5-10 then explain the contents of the letter with a discussion of the nature of God and the nature of the fellowship of sinners with God. Where, the writings of 1 John describe the very contrast between light and dark. It is worth noting that this painting is commonly found in John's writings, such as John's Gospel and 1 John. The studies will be discussed using epistolary hermeneutics as a way of analyzing 1 John 1: 5-10.
\end{abstract}

Key words: Light and Dark, Epistolary Hermeneutics

\section{Pendahuluan}

Para Sarjana Alkitab seringkali memberikan perdebatan ataupun pertentangan terhadap Surat-surat Yohanes, terutama merujuk pada tanggal kepengarangan, tempat, dan interpretasi mereka. Teks yang dikenal sebagai 1 Yohanes menambahkan jenis sastra pada kumpulan-kumpulan topik yang diperdebatkan. Dalam hal tersebut, surat ini tidak berisi pembukaan atau penutupan sebagaimana jenis sastra epistolary yang terdengar begitu akrab dari tulisan-tulisan di dalam alkitab, yaitu fitur-fitur tulisan yang secara konsisten ada dalam surat-surat Paulus. ${ }^{1}$ Meskipun berada di luar cakupan makalah ini untuk menjelaskan dan mempertimbangkan semua bukti dalam masing-masing topik, penulis akan menegaskan untuk memusatkan diri dalam mengekseges is 1 Yohanes 1:510 .

\footnotetext{
${ }^{1}$ Unsur-unsursurat Paulus memiliki kesamaan dengan surat-surat kuno dalam bentuk standar (tanggal, salam, tubuh surat, penutup, dan tanda tangan). Ribuan surat kuno telah ditemukan dan kebanyakan dari surat-surat tersebut mempunyai bentukyang tepat sama dengan surat-surat yang ada di Perjanjian Baru (band. Surat dari Majelis di Yerusalem di Kis. 15:23-29). Douglas Stuart dan Gordon D. Fee, How to Read the Bible for All Its Worth (Grand Rapids: Zondervan, 1993), 50-51.
} 
Dengan beberapa sumber yang jelas, hubungan-hubungan secara konsep dan linguistik antara Surat-surat Yohanes dan Injil Yohanes menyarankan kepada seorang penulis tunggal, yaitu rasul Yohanes. Sosok ini di dalam Injil Yohanes dikatakan sebagai "murid yang dikasihi," yang juga menyusun ketiga suratnya pada beberapa waktu kemudian yaitu 1, 2 dan 3 Yohanes. ${ }^{2}$ Secara khas, pembaca 1 Yohanes telah mengakui sisi polemik dari beberapa pernyataan Yohanes, dimana ia bermaksud untuk memerangi ajaran palsu tertentu yang beredar di antara gereja-gereja di Asia kecil. ${ }^{3}$ Namun, beberapa Sarjana Alkitab berpendapat bahwa pernyataan-pernyataan polemik ini seolah-olah tidak dibaca sebagai ajaran spesifik yang menantang; Sebaliknya, mengingat "pernyataan tujuan" dari Yohanes yang secara jelas ada di sepanjang surat tersebut, khususnya terletak pada 1 Yohanes 5:13 "semuanya itu kutuliskan kepada kamu, supaya kamu yang percaya kepada nama Anak Allah, tahu bahwa kamu memiliki hidup yang kekal." 1 Yohanes hanyalah sebuah surat pastoral, yang berusaha untuk "memperkuat kepercayaan dan nilainilai yang dipegang sebagai penerapan pribadi." ${ }^{5}$ Mengikuti "pernyataan tujuan" dari surat 1 Yohanes, tampaknya tujuan dari surat tersebut merujuk kepada ajaran-ajaran pastoral, namun juga memilki polemik dalam kategori ini. ${ }^{6}$

Rasul Yohanes juga menulis surat untuk memastikan dan meyakinkan jemaat Asia Kecil bahwa mereka sungguh-sungguh mengenal Allah (1 Yoh. 2:12-14), ${ }^{7}$ dan sepanjang tulisannya ia menggunakan beberapa ajaran palsu (Gnostikisme) yang berkembang pada pembaca atau komunitasnya sendiri, sebagai permasalahan yang terjadi pada masa itu. ${ }^{8}$ Dengan demikian, Yohanes mungkin memasukkan unsur-unsur polemik untuk memperingatkan gereja-gereja lain di sekitar Asia Kecil tentang beberapa penjelasan dari guru-guru palsu yang telah "pergi-keluar" dari gereja/persekutuan orang-

${ }^{2}$ Andreas J. Köstenberger, Encountering John: Injil dalam Perspektif Sejarah, Sastra dan Teologis (Malang:SAAT, 2015), 20-21.

${ }^{3}$ Merril C. Tenney, Survey Perjanjian Baru (Malang: Gandum Mas, 2000), 463.

${ }^{4}$ Penjelasan ini dimaksudkan kepada para pembaca yang merupakan orang-orang percaya di dalam Kristus. Frase mengenai "percaya kepada nama anak Allah" dalam ayat 5 juga mengulangi beberapa frase yang dipakai oleh Yohanes dalam kitab 1 Yohanes sebagai iman yang murni, seperti: "lahir dari Allah" (ay. 18), "berasal dari Allah" (ay. 19), "mengenal yang benar" (ay .20), dan "ada di dalam yang benar (ay. 20). Roy B. Zuck, Darrel Bock, A Biblical Theology of The New Testament (Malang: Gandum Mas), 260

5 Tenney, Survey Perjanjian Baru, 466.

${ }^{6}$ Ibid, 464.

7 Thomas R. Schreiner, New Testament Theology (Yogyakarta: ANDI, 2015), 102.

${ }^{8}$ Kesalahan khusus yang nampaknya ingin diperangi 1 Yohanes adalah gejala awal dari Gnostikisme, suatu ajaran sesat yang menajdi bahaya terbes ar bagi gereja hingga akhir abad yang kedua. Gnostikisme adalah suatu filsafat agama bukan suatu sistem tersendiri. Ia dibangun berdasarkan anggapan bahwa roh adalah baik, tubuh adalah jahat, dan di antara keduanya tidak mungkin ada suatu hubungan yang kekal. Tenney, Survey Perjanjian Baru, 464. 
orang percaya dan mungkin saja jemaat Asia kecil salah mengartikan ajaran Yohanes seperti yang ditemukan dalam Injil. ${ }^{9}$

Empat ayat pertama dari surat ini secara luas diakui sebagai prolog atau pengantar surat yang secara keseluruhan memiliki banyak kedekatan dengan prolog Injil Yohanes. Pengantar surat ini berfungsi untuk menetapkan kesaksian pribadi Yohanes yang menjelaskan tentang kehidupan kekal dan pribadi, serta karya Yesus Kristus. Yohanes juga memperkenalkan beberapa tema utama yang dibahas dalam bagian dari surat ini, yaitu: kehidupan, kesaksian, persekutuan, dan hubungan Bapa dan Yesus Kristus. Ayat 5-10 kemudian menjelaskan isi surat dengan diskusi tentang sifat Tuhan dan sifat persekutuan orang berdosa dengan Allah. Dimana, tulisan 1 Yohanes memaparkan hal yang sangat kontras antara terang dan gelap. Memang perlu diperhatikan bahwa lukisan ini banyak ditemukan dalam tulisan-tulisan Yohanes, seperti Injil Yohanes dan 1 Yohanes. ${ }^{10}$

Dari sudut pandang yang lain, ayat 5-10 juga memperkenalkan topik dosa dalam kehidupan orang percaya yang juga dapat dikunjungi dua kali lagi dalam surat ini (3: 4-10; 5: 16-18). Motif teologis lain yang diperkenalkan atau dikembangkan dalam ayat 5-10 mencakup persekutuan dengan Tuhan antara orang percaya, keberlawanan antara kepalsuan dan kebenaran, kematian Yesus, pembersihan, pengampunan dan pengakuan dosa, serta kehendak Tuhan dan kesetiaan dan kebenaran / keadilan. Oleh sebab itu, Yohanes memulai suratnya dengan penyelidikan teologis yang padat tentang bagaimana manusia berdosa yang dapat mengalami persekutuan sejati dengan Tuhan.

Dari pemaparan di atas, judul paper "Studi analisis mengenai maksud Allah adalah Terang dan hubungannya dengan orang percaya yang mengaku dosa-dosanya menurut 1 Yohanes 1:5-10" akan dibahas oleh penulis dengan memperhatikan 6 bagian utama, pertama, terjemahan 1 Yohanes 1:1-5. Kedua, Maksud "terang dan gelap" dalam kepenulisan Yohanes (ay. 5). Ketiga, tiga pernyataan bersyarat dan fungsi retorisnya dalam 1 Yohanes 1:6, 8, 10. Keempat, Peningkatan maksud dari "kebohongan dirinya sendiri" (ay.8) terhadap "Allah sebagai Pembohong" (ay.10). Kelima, Hubungan Antara Berjalan dalam Terang dan Pengakuan Dosa (ay.7, 9). Keenam, Berjalan di dalam Terang hanya terjadi atas dasar pembersihan dan kematian Yesus Kristus. Ketujuh, Hubungan Antara Pengakuan dan Pengampunan Dosa, dan bagian terakhir adalah kesimpulan dari keseluruhan analisis ini.

\section{Terjemahan 1 Yohanes 1:5-10}

${ }^{5}$ Dan inilah pesan yang telah kami dengar dari-Nya dan kami sampaikan kepadamu: "Allah itu terang dan sama sekali tidak ada kegelapan di dalam Dia." 6 Jika kami sekali berkata yaitu bahwa kami memiliki persekutuan dengan-Nya dan jika kami terus berjalan dalam kegelapan maka kami sedang menipu diri kami sendiri dan kami

\footnotetext{
${ }^{9}$ Dengan rekonstruksi umum ini, Penulis juga menemukan saran-saran dari kitab 2 Yohanes yang mungkin telah bertugas sebagai surat pelindung bagi kitab 1 Yohanes, supaya memberikan pencerahan bagi para pembaca utama. Frank J. Matera, New Testament Theology: Exploring Diversity and Unity (Louis ville: Westminster John Knox, 2007), 319.

${ }^{10}$ Zuck, Darrel L. Bock, A Biblical Theology, 231.
} 
tidak melakukan kebenaran itu. ${ }^{7}$ Tetapi jika kita berjalan di bawah terang, seperti yang ada dalam terang, kita mengalami persekutuan satu sama lain dan darah Yesus, AnakNya, membersihkan kita dari segala dosa. ${ }^{8}$ Jika kita sekali berkata bahwa hakekat dosa tidak memiliki dosa maka kita menipu diri kita sendiri dan kebenaran itu tidak ada di dalam kita. ${ }^{9}$ Jika kita mengakui dosa-dosa kita, Ia akan mengampuni dosa-dosa kita dan menyucikan kita dari segala keasalahan, karena Ia setia dan adil untuk melakukannya. ${ }^{10}$ Jika kita sekalian berkata yaitu bahwa kita tidak berdosa maka kita melakukan dusta dan firmanNya tidak di dalam kita.

\section{Garis Besar Eksegesis}

I. Allah adalah Terang (1:5)

II. Perbedaan antara seseorang yang berjalan dalam terang dan gelap dengan konsekuensi tindakannya (1:6-7)

A. Berjalan dalam kegelapan mengungkapkan suatu pengalaman terhadap persekutuan dengan Tuhan yang menjadi Salah (1:6)

B. Berjalan di Terang Allah mengungkapkan pengalaman sejati terhadap persekutuan satu sama lain dan menerima pembersihan dari setiap dosa karena kematian Yesus (1:7)

III Dosa Tetap menjadi realita bagi mereka yang mengalami persekutuan dengan Tuhan; Pengakuan terhadap dosa, serta penyangkalan dosa (1: 8-10)

A. Mengklaim tidak memiliki dosa mengungkapkan penipuan diri dan pemutusan kebenaran Allah (1:8)

B. Mengakui perbuatan dosa dalam pengampunan dan pembersihan karena kesetiaan dan keadilan Tuhan (1:9)

C. Mengklaim bukan seorang Pendosa memanggil Allah sebagai Pendusta dan Pemutusan dari Firman Allah (1:10)

\section{Maksud "Terang dan Gelap" dalam Kepenulisan Yohanes (ay.5)}

Dalam tulisan pembukaannya, Yohanes merujuk pada "apa yang telah kita dengar" (1 Yoh.1:1), yang mengindikasikan kata kerja jamak orang pertama, baik dirinya sendiri sebagai penulis surat atau dirinya sendiri, yang juga dianggap sebagai bagian saksi mata dari kelompok para rasul, serta pembaca utama dari surat 1 Yohanes yaitu jemaat dari Asia Kecil. ${ }^{11}$ Dalam 1: 5, Yohanes menggunakan ketentuan sastra yang sama,

\footnotetext{
${ }^{11}$ Richard Bauckham, Jesus and the Eyewitnesses: The Gospels as Eyewitness Testimony (Grand Rapids: Eerdmans, 2006), 370.
} 
dimana ia menulis pembukaan isi surat yang didengar "darinya,"12 yaitu Yesus Kristus yang merupakan anteseden dari kata $\alpha$ v่ oṽ. ${ }^{13}$ Klausa berikutnya, memperkenalkan topik utama dari paragraf ini, ${ }^{14}$ yaitu meringkas pernyataan Yohanes kepada pembacanya, dengan mengatakan, "Tuhan itu terang dan sama sekali tidak ada kegelapan darinya." ${ }^{15}$ Dua bagian antara terang dan gelap adalah tema yang umum dalam Injil Yohanes (Yohanes $1: 4-9 ; 3: 19-21 ; 5: 35 ; 8: 12 ; 9: 5 ; 11: 9-10 ; 12: 35-36,46)$, dimana ayat-ayat tersebut juga muncul dalam 1 Yohanes 2: 8-11. ${ }^{16}$ Menurut Charles P.Baylis, Yohanes menghubungkan konsep lain yang behubungan dengan terang seperti kehidupan, kebenaran, dan penyataan/wahyu, serta, ia menghubungkan konsep kegelapan yang lainnya seperti kebutaan, kebohongan, dan kejahatan. ${ }^{17}$ Penggunaan terang yang beragam oleh Yohanes merupakan metafora yang berkaitan dengan pribadi dan karya Yesus, karena ia membuat hubungan utama tentang kehidupan dan terang yang eksplisit diterangkan dalam Yohanes 1: $4 .^{18}$

\section{Kesimpulan Analisis 1 Yohanes 1:5}

Yohanes mempertahankan pemisahan antara terang dan gelap. Dengan demikian, segala sesuatu (semua orang) yang terkait dengan "terang" terhubung dengan Allah dan keselamatan, dan segala sesuatu (semua orang) yang terkait dengan "kegelapan" terhubung dengan dosa dan maut. ${ }^{19}$ Jika memperhatikan kalimat di atas, maka Yohanes menerapkan kata 'terang' sebagai suatu metafora yang mengarahkan langsung kepada Tuhan dan juga berfungsi sebagai ringkasan tentang pesan-pesan dari surat-suratnya. David A. deSilva menganggap bahwa Konstruksi Yohanes tentang suatu

\footnotetext{
${ }^{12}$ Raymond E. Brown menganjurkan bahwa kata $\alpha \gamma \gamma \varepsilon \lambda i ́ \alpha$ dalam 1:5 bisa menjadi sinonim dari kata $\varepsilon \dot{\alpha} \gamma \gamma \varepsilon \dot{\lambda} 10 v$, terutama karena ia tidak menggunakan istilah yang terakhir sebagaiakusatif. Raymond E. Brown, The Epistles of John (New Haven: Yale University Press, 2008), 193.
} Mas, 2001), 1040.

${ }^{13}$ Charles F. Pfeiffer, Everret F. Harris on, The Wycliffe Bible Commentary (Malang:Gandum

${ }^{14}$ Steven E. Runge, A Discourse Grammar of the Greek New Testament: A Practical Introduction for Teaching and Exegesis (Bellingham: Logos Research Systems, 2010), 438. sudut pandang yang lain bisa dilihat sebagai klausa mengenai "pernyataan sentraldari suratnya." Robert W. Yarbrough, 1 3 John ( Grand Rapids: Baker Publisher, 2008), 48.

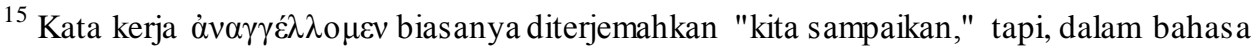
Inggris, hal ini sering berkonotasi terhadap informasi yang baru diberikan, dan tampaknya Yohanes mengharapkan kepada setiap pembaca di Asia kecil untuk memahami pesan teologis yang ia

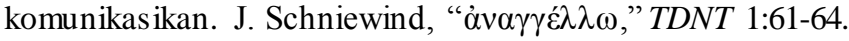

${ }^{16}$ Zuck, Darrel L. Bock, A Biblical Theology, 232.

${ }^{17}$ Charles P. Baylis, “The Meaning of Walking 'in the Darkness' (1 John 1:6),” BSac 149:594 (Apr. 1992): 216

${ }^{18}$ Daniel L. Akin, 1, 2, 3 John (Nashville: Broadman \& Holman, 2001), 64.

${ }^{19}$ Carey C. Newman, Dictionary of the Later New Testament and Its Developments(Illinois: InterVarsity, 2000), np. 
realitas yang "berlawanan" menyajikan pembacanya dengan seruan untuk hidup selaras dengan "terang," dimana merujuk pada kodrat Allah dengan memandangNya sebagai Allah yang kudus bagi kehidupan etika orang percaya, serta menolak segala sesuatu yang berhubungan dengan "gelap." 20 Oleh sebab itu, frase mengenai "Allah adalah terang" menunjukkan bahwa Allah adalah kudus, karena tidak ada kegelapan di dalam Allah. Setiap orang yang mengklaim telah mengenal Allah, tetapi melakukan kejahatan bertentangan dengan perilakunya sebagaimana esensi Allah yang adalah terang. ${ }^{21}$

Yohanes mengidentifikasi beberapa implikasi dari kebenaran-kebenaran teologis ini untuk memberikan cara (pola hidup) bagi orang-orang percaya, supaya mereka hidup dalam kebenaran. Serta, mengekspresikannya dalam bentuk serangkaian lima kalimat bersyarat dan bergantian antara tiga pernyataan negatif dan dua pernyataan positif, yang dibingkai oleh dua bagian yang tampaknya berlawanan (polarization) yaitu terang dan gelap. ${ }^{22}$ Tiga pernyataan bersyarat negatif memang berdiri secara paralel (sejajar), demikian juga dua pernyataan positif, sehingga akan sangat membantu untuk mempertimbangkan pernyataan yang negatif secara bersama-sama, maupun juga pernyataan yang positif. $^{23}$

\section{Tiga Bagian Pernyataan Bersyarat dan Fungsi Retoris nya dalam 1 Yohanes 1:6, 8, 10}

Konstruksi gramatikal dari kata éóv dengan kata kerja subjungtif dari kata kerja $\epsilon " m \omega \mu \epsilon \nu$ menunjukkan 3 bagian pernyataan bersyarat (kondisional), dimana Yohanes menyajikan "beberapa tindakan atau peristiwa dalam pertimbangan hipotetis." 24 Hal ini dapat dimaksudkan bahwa seorang penulis dapat menggunakan konstruksi ini dengan berbagai keperluan retoris. ${ }^{25}$ Yohanes menggunakan konstruksi ini berkali-kali dalam suratnya, dan tampaknya ia melakukan untuk menasihati pembaca Asia kecil untuk

${ }^{20}$ David A. deSilva, An Introduction to the New Testament: Contexts, Methods and Ministry Formation(Illinois.: InterVarsity, 2004), 469. Charles F. Pfeiffer, Everret F. Harrison, The Wycliffe Bible Commentary, 1040.

${ }^{21}$ Schreiner, New Testament Theology, 102.

${ }^{22} \mathrm{Hal}$ ini menunjukkan bahwa 4 bagian ayat dari tulisan-tulisan Yohanes memberikan pernyataan tentang "Allah" yang didapatkan dalam Yohanes 4:24; 1 Yohanes 1: 5; 4: 8, 16.Dimana masing-masing ayat mengungkapkan penerapan praktis bagi kehidupan Kekristenan. B.F. Westcott, Epistles of Saint John (New York: Macmillan, 1902), 17.

${ }^{23}$ Christopher D. Bass, That You May Know: Assurance of Salvation in 1 John (Nashville: Broadman\&Holman Publishers, 2008), 67.

${ }^{24}$ Stanley E. Porter, Idioms of the Greek New Testament (Sheffield: JSOT, 1999), 262.

${ }^{25}$ Dalam memperhatikan fungsiatau keperluan retoris, salah satu yang harus diperhatikan adalah gaya bahas anya.1 Yohanes 1:6,8, dan 10 memaparkan gayabahasa dengan pemilihan ungkapan, frasa, dan kalimat dengan beberapa "pengalihan"/ metafora atau penggunaan bahasa kiasan. Petrus Maryono, Analisis Retoris: Suatu Teknik Studi Hermeneutik terhadap Teks Alkitab (Yogyakarta: ANDI, 2016). 
berperilaku atau merespons dengan cara tertentu. ${ }^{26}$ Banyak penafsir menyarankan bahwa pernyataan negatif yang berada pada ayat 6, 8, 10 benar-benar mencerminkan "slogan" terhadap beberapa "lawan-lawan Yohanes," Tetapi pernyataan ini layak untuk berdiri sendiri karena pengajaran dan nasihat Yohanes bagi para pembacanya di Asia kecil (dalam bahasa Yunani memakai referensi dari orang pertama jamak dari kata kerja

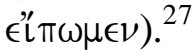

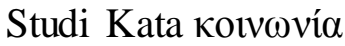

Paragraf ini (ay.5-10) menjelaskan tentang persekutuan, yang mana menghubungkannya dengan salam pembuka (prolog) dari surat 1 Yohanes. Rasul Yohanes menyatakan suatu tujuan dari surat ini kepada pembacanya tentang apa yang ia dengar yaitu mereka yang akan mengalami persekutuan denganNya, yang sebenarnya adalah persekutuan dengan Bapa dan Yesus Kristus. Di luar kata-kata pembukaan ini

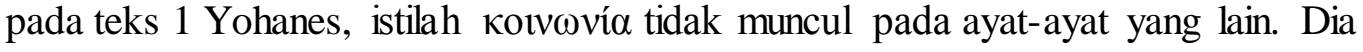
menggunakan kata kerja है $\chi \omega$ untuk menunjukkan bahwa pembagian relasi ini dapat dialami oleh setiap pembacanya. ${ }^{28}$ Dengan memperhatikan ayat-ayat pembuka dari surat 1 Yohanes, secara mengejutkan tidak ditemukan istilah terhadap penggunaan kata

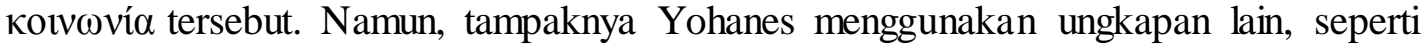
"mengenal Tuhan" (2: 3-6) atau "tinggal di dalam Allah" (2: 6, 24; 3:24; 4:13, 15-16). Jadi, inilah gagasan yang dengannya Yohanes mengembangkan suatu pengalaman tentang persekutuan dengan Tuhan dan sesama orang percaya, sehingga "persekutuan ini melibatkan komitmen terhadap kepercayaan yang mendasar (doktrin) dan kesetiaan dalam kehidupan yang taat kepada Tuhan," serta mencintai Tuhan dan mencintai orang percaya lainnya. ${ }^{29}$ Dengan kata lain, penulis menganggap bahwa Yohanes memahami "pengalaman tentang persekutuan dengan Allah" sebagai pemahaman terhadap suatu pengalaman keselamatan dan semua kepentingan yang berhubungan dengan hubungan pribadi kepada Yesus Kristus, serta menghubungkan dengan tujuannya yang dinyatakan dalam 1 Yohanes 5:13, karena ia menyediakan berbagai bukti tentang Allah. Pembaca harus melihat dalam kehidupan mereka sendiri apakah mereka mengalami persekutuan dengan Tuhan yang ditunjukan dalam kehidupan pribadinya. Relasi inilah menunjukan tentang kehidupan dan terang Tuhan yang dimanifestasikan di dalam Yesus Kristus.

${ }^{26}$ Di luar tiga bagian pernyataan kondisional ini, lihat juga dalam 1 Yohanes 2:15, 24; 4:12, 20; 5:14, 15, 16. Martin M. Culy, I, II, III John: A Handbook on the Greek Text (Waco, Tex.: Baylor University Press, 2004), 18-19.

${ }^{27}$ Ben Witherington III, Letters and Homilies for Hellenized Christians Volume 1: A SocioRhetorical Commentary on Titus, 1-2 Timothy and 1-3 John (Illinois.: InterVarsity, 2006), 450.

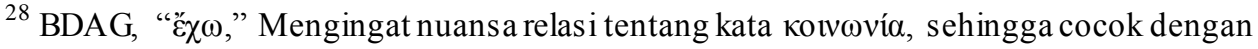
"orang yang memiliki kasih."

${ }^{29}$ Robert W. Yarbrough, "1 John,” in Zondervan Illustrated Bible Backgrounds Commentary Volume 4: Hebrews to Revelation (ed. Clinton E. Arnold; Grand Rapids: Zondervan, 2002), 183. 
Maksud mengenai orang percaya yang "hidup dalam kegelapan" (ay.6b)

Setiap pernyataan negatif ada hubungannya dengan pernyataan yang tidak sesuai dengan kenyataan. Pernyataan terhadap persekutuan dengan Tuhan akan selalu berbeda oleh "si penggugat" yang berjalan dalam kegelapan. Hidup dalam kegelapan merupakan metafora Yahudi yang umum bagi gaya hidup seseorang, dimana Yohanes mencirikan gaya hidup tersebut seperti "orang yang hidup dalam kegelapan" (ay.6). Yohanes juga mencatat pernyataan Yesus dengan menggunakan metafora Yahudi terhadap seseorang yang berjalan dalam kegelapan seperti tercatat pada Yohanes 8:12 dan 12:35. Dalam 1 Yohanes, ungkapan tersebut muncul kembali dalam 2:11, yang menunjukkan bahwa "orang tersebut tidak tahu kemana ia pergi, karena kegelapan itu telah membutakan matanya.",30

Kesejajaran ini dapat ditemukan dalam ayat 8 bahwa seseorang dapat mengklaim untuk tidak "memiliki dosa." Frase ini juga ada dalam Yohanes 9:41; 15:22, 24; dan 19:11, dan masing-masing konteks ini nampaknya relatif jelas bahwa ungkapan tersebut menunjukkan kepada seseorang yang bersalah atas dosa-dosanya. ${ }^{31}$ Oleh sebab itu, dalam ayat 10, Yohanes menggunakan kata kerja perfek tense dari kata $\alpha \mu \alpha \rho \tau \alpha ́ v \omega$. dimana satu-satunya terjadi dalam Perjanjian Baru dari bentuk kata kerja ini, namun muncul 33 kali dalam Septuaginta (LXX), dan biasanya secara jelas mengacu pada status seseorang yang bersalah di hadapan Tuhan. ${ }^{32}$ Jadi, frase mengenai "berjalan dalam kegelapan," "memiliki dosa," dan "bersalah atas dosa" memiliki kesepadanan/kesetaraan secara sematik.

Meskipun demikian, Yohanes mungkin menginginkan beberapa nuansa retoris saat ia menggunakan ungkapan-ungkapan yang berbeda ini. "Berjalan dalam kegelapan" secara langsung mengacu pada kiasan yang digunakan dalam 1 Yohanes 1:5, yang mungkin saja menunjukkan ketidakcocokan pernyataan ini dengan "seseorang yang mengalamai pengalaman persekutuan dengan Allah." Dimana Yohanes mengungkapkan secara halus adanya kemungkinan bahwa orang percaya masih "hidup di dalam kegelapan," yang tidak sesuai dengan kehendak Allah yang adalah "terang" itu sendiri.

\section{Maksud mengenai orang percaya yang “tidak melakukan kebenaran” (ay.6d)}

Kesimpulan dari pernyataan bersyarat (apodisis) pada ayat enam menunjukan bahwa seseorang yang memiliki persekutuan dengan Tuhan, namun hidupnya dalam kegelapan, gaya hidupnya terserap oleh kesalahan dosa dan tidak mempraktikkan kebenaran. Ungkapan "tidak mempraktekkan kebenaran" dipahami sebagai dasar yang sama terhadap seseorang yang berdusta. ${ }^{33}$ Oleh sebab itu, Yohanes secara retoris menjelaskan tentang penghukuman kepada orang-orang munafik yang sebenarnya

${ }^{30}$ Bass, Assurance, 68.

${ }^{31}$ Yarbrough, 1-3 John, 59, Bass, Assurance, 70.

${ }^{32}$ Fokus utama Yohanes dalam berbicara tentang kegelapan adalah tidak adanya terang (yaitu, tidak adanya kehidupan, yang berarti kematian). Akin, 1, 2, 3 John, 67, 99.

${ }^{33}$ Culy, I, II, III John, 15. 
mengetahui kebenaran itu. Namun, maksud dari kata "berdusta" mungkin saja dimaksudkan untuk mengomentari pernyataan bersyarat dalam penjelasan ayat ini, sementara pernyataan untuk tidak "mempraktekkan kebenaran" mungkin dimaksudkan untuk mengomentari seseorang yang "berjalan dalam kegelapan." ${ }^{34}$ Frase tanpa negasi (kata sangkalan) juga terjadi dalam Yohanes 3:21,dimana sangat berkaitan erat dengan seseorang yang melakukan perbuatan baik. Hal Ini mencerminkan sebuah ungkapan Semitik yang muncul di Qumran dan beberapa teks PL yang mungkin diterjemahkan secara harfiah di LXX (Septuaginta). Menurut Louw-Nida, ia juga menyarankan suatu tindakan yang "sesuai dengan kebenaran." 35 Namun begitu, hal ini membawa penulis dan pembaca bertanya, seperti perkataan Pilatus, "Apa itu kebenaran?" (Yohanes 18:38).

Dalam Injil Yohanes dan surat-suratnya, maksud dari kata "kebenaran" menjadi motif atau tema utama dalam kepenulisan Yohanes. Dalam surat-surat tersebut, Yarbrough mengidentifikasi lima kategori penggunaan yang relatif berbeda. ${ }^{36}$ Turner mencoba untuk membantah bahwa hampir setiap penemuan kata dari $\dot{\alpha} \lambda \eta \dot{\theta} \theta \varepsilon \iota \alpha$ dalam tulisan Yohanes mengacu pada Yesus sendiri. ${ }^{37}$ Namun dari pada itu, kata "kebenaran" diketahui secara dekat dengan pribadi Yesus dalam tulisan-tulisan Yohanes, "kebenaran" juga tidak secara eksklusif diidentifikasi dengan Yesus (Yoh:18:37); ${ }^{38}$ Kebenaran ini juga berkaitan dengan Roh (misalnya Yohanes 15:26; 1 Yohanes 5:6) dan secara umum menjelaskan tentang Tuhan itu sendiri (misalanya Yohanes 3:33; 8:26).

Frase "tidak mempraktekkan kebenaran" dalam 1 Yohanes 1: 6 memiliki kesejajaran dengan frase "kebenaran tidak ada di dalam kita"39 dalam 1Yohanes 1: 8 dan dengan ungkapan "firman-Nya tidak ada di dalam kita" dalam 1 Yohanes 1:10. Dalam Yohanes 17:17, Yesus mengatakan bahwa firman Allah adalah kebenaran. Lebih dari itu, 1 Yohanes 2: 4 mengatakan bahwa kebenaran tidak ada pada orang yang tidak mematuhi perintah-perintah Allah. Jadi, kemungkinan dari kesimpulan ini yaitu bahwa "melakukan kebenaran" ada kaitannya dengan gaya hidup seseorang yang sesuai dengan firman Allah, ataupun perintah-perintah-Nya. ${ }^{40}$ Dengan kata lain, "melakukan kebenaran" adalah ciri khas dari perbuatan-perbuatan ataupun kata-kata yang keluar dari setiap orang percaya. Oleh karena itu, seseorang yang dibicarakan dalam ayat 6 yang "mengaku mengalami persekutuan dengan Tuhan namun berjalan di dalam kegelapan," memiliki sebuah

\footnotetext{
${ }^{34}$ Westcott, Epistles, 19.

${ }^{35}$ LN 41.7, “A Behavior, Conduct,” 1:504. Witherington, Homilies, 451, Menyarankan gagasan untuk"menerapkan teologi seseorang."

${ }^{36}$ Robert W. Yarbrough, "2 John,” in Zondervan Illustrated Bible Backgrounds Commentary Volume 4: Hebrews to Revelation (ed. Clinton E. Arnold; Grand Rapids: Zondervan, 2002), 215-216.

${ }^{37}$ Nigel Turner, Grammatical Insights into the New Testament (Edinburgh: T\&T Clark, 1966), 8-11.

${ }^{38}$ Leon Morris, Teologi Perjanjian Baru (Malang:Gandum Mas, 2014), 392.

${ }^{39}$ Ini didasarkan pernyataan kepada iblis dalam Yohanes 8:44.

${ }^{40} \mathrm{Hal}$ ini serupa dengan kesimpulan Bass, Assurance, 69, dia juga ingin menghubungkan wahyu ini dengan sangat erat pada karya-karya Yesus.
} 
pengertian bahwa dia membuat klaim atau pernyataan palsu dengan menunjukan tingkah lakunya yang berdosa, hal ini disebabkan oleh dia yang tidak bertindak sesuai dengan kebenaran dari penyataan Tuhan, yang berhubungan erat dengan pribadi Yesus Kristus.

\section{Peningkatan maksud dari "kebohongan dirinya sendiri" (ay.8) terhadap}

\section{"Allah sebagai Pembohong" (ay.10)}

Masing-masing pernyataan negatif berfokus pada pernyataan bahwa seseorang dapat membuat sesuatu namun apa yang dibuatnya tidak sesuai dengan kenyataan; Dua pernyataan terakhir tidak pernah sesuai dalam keadaan apapun, sementara pernyataan pertama berpotensi sama, namun tidak sesuai bagi seseorang yang gaya hidupnya di dalam dosa, yang terputus dari terang Allah. Dalam kasus pertama, seseorang yang berjalan tidak sesuai dengan pernyataannya (klaimnya), ia hanya membuat suatu pernyataan yang palsu (ay.6). Namun, dalam kasus kedua, jika seseorang mengklaim bahwa ia tidak menanggung kesalahan karena ia berdosa, Yohanes mengatakan bahwa orang tersebut menipu dirinya sendiri (ay. 8). Yohanes mengakui dalam 1 Yohanes 2:26 bahwa ada beberapa orang yang mencoba berbohong kepada pembacanya, namun dia menyerang suatu penghubung yang sangat berbeda, dimana ia menunjukkan bahwa orang-orang yang membuat pernyataan semacam itu hanyalah seseorang yang menipu dirinya sendiri dan tidak mengenal dirinya dengan benar. ${ }^{41}$ Oleh sebab itu, dalam kasus ketiga (ay.10), pernyataannya hampir memiliki kesamaan dengan pernyataan yang kedua (ay. 8), dimana orang ini mengalihkan fokus dari apa yang sebenarnya diungkapkan oleh pernyataan tersebut kepada seseorang yang mengajukan pernyataan seperti apa yang dikatakannya kepada Allah. ${ }^{42}$ Seseorang yang mengaku tidak berdosa membuat "Allah menjadi pendusta" (ay.10), hal tersebut dapa diartikan bahwa orang ini secara langsung bertentangan dengan perkataan-perkataan Allah mengenai keberadaannya sebagai manusia, dimana manusia adalah pendosa, dan juga berarti bahwa manusia menolak ketetapan Allah yang berkatian pada keselamatan dalam kematian Yesus Kristus. ${ }^{43}$ Yohanes menggunakan suatu akusatif ganda dengan kata kerja $\pi$ oı́́ $\omega$ di mana juga merujuk kepada kata ganti av̉ òv yang mengacu kepada Allah sendiri sebagai suatu objek, ${ }^{44}$ dan kata akusatif $\psi \varepsilon v ́ \sigma \tau \eta v$ adalah pelengkap (complement) ${ }^{45}$ yang memberikan pernyataan untuk menunjukkan bahwa seseorang yang membuat pernyataan ini memiliki

${ }^{41}$ Tema mengenai "penipuan dirinya sendiri" ini juga ada dalam Perjanjian Lama seperti dalam Mzm 36: 1-4; Yer 2: 34-35; 17: 9-10.

${ }^{42}$ Runge, Discourse, 272.

${ }^{43}$ Alan E. Brooke, A Critical and Exegetical Commentary on the Johannine Epistles (ICC; New York: Scribner's Sons, 1912), 21. Frase mengenai “tidak berbuat dosa” mengacu

${ }^{44}$ Bass, Assurance, 72.

45 Daniel B. Wallace, Greek Grammar Beyond the Basics: Exegetical Syntax of the New Testament (Grand Rapids: Zondervan, 1996), 182-9. 
tujuan untuk melakukan suatu kebohongan, bukan hanya menipu dirinya sendiri, namun juga menghujat/menghina dengan menyatakan bahwa Allah itu sebagai pembohong. ${ }^{46}$

\section{Hubungan Antara Berjalan dalam Terang dan Pengakuan Dosa (ay.7, 9)}

Yohanes membuat dua pernyataan positif dalam paragraf ini yang berdiri sejajar antara satu dengan yang lainnya. Ayat 7 dan 9 tidak hanya sejajar satu sama lain, tetapi juga memberikan tanggapan paralel terhadap pernyataan yang diucapkan masingmasing. Oleh Sebab itu, dalam ayat 6, Yohanes mempertimbangkan situasi seseorang yang berjalan dalam kegelapan, dan dalam ayat 7 , Yohanes juga menganggap situasi seseorang yang berjalan dalam terang. Demikian juga, dalam ayat 8 , dimana Yohanes telah mempertimbangkan seseorang yang akan menyangkal kesalahan dari dosanya, dan dalam ayat 9, Yohanes menganggap seseorang yang mengakui dosanya. Di seluruh paragraf ini, hanyalah ayat 7 yang berisi gabungan untuk menghubungkan satu kalimat dengan kalimat lainnya. Yohanes menghubungkan ayat 6 dan ayat 7 dengan memakai konjungsi $\delta \dot{\varepsilon}$, yang menyoroti secara kontras antara berjalan dalam kegelapan dan berjalan di bawah terang, dan menghubungkan pasangan ayat ini lebih dekat dengan ayat 5 .

Selain itu, Yohanes menggunakan artikel $\tau \hat{\omega}$ dengan kata benda datif $\varphi \omega \tau \grave{i}$ (yaitu terang) dalam ayat 7 untuk menunjukan kembali kata benda $\varphi \tilde{\omega} \varsigma$ (yaitu terang) dalam ayat 5. ${ }^{47}$ Sedangkan secara metafora, Allah disamakan dengan terang pada ayat 5 , hal ini menjelaskan bahwa Allah sendiri adalah terang, dan Yohanes menganggap suatu kenyataan dimana Allah yang berjalan di dalam terang. ${ }^{48}$ Barangkali dapat dimengerti secara baik bahwa Yohanes menggeser dari persamaan metafora antara Allah dengan terang untuk berbicara tentang Allah yang berada di bawah terang, dimana secara wajar dapat dilihat bahwa Allah tinggal dalam terang itu. ${ }^{49}$ Allah menunjukan kualitasnya yang berkaitan tentang terang itu sendiri, seperti kebenaran, dan keadilan. Di tempat lain, Yohanes berbicara tentang orang-orang yang berjalan dalam kebenaran (2 Yohanes $4 ; 3$ Yohanes 3-4), hidup dalam perintah-perintah Allah (2 Yohanes 6), serta penjelasan tentang "hari" dalam Yohanes 11: 9, yang mana hal ini dihidupi bagi seseorang yang

${ }^{46}$ Yarbrough, 1-3 Yohanes, 66. Pernyataan ini dapat dilihat sebagai versi ataupun pernyataan Yohanes terhadap "penghujatan terhadap Roh", karena dari sisi Markus 3: 22-30 menghubungkan penghujatan semacam ini dengan memuji terhadap karya Yesus kepada kuasa Ib lis, dan Yohanes 8:44 menyebutkan bahwa Iblis itu adalah pembohong. Oleh sebab itu, menyebut Tuhan sebagai pembohong pada dasarnya menyamakan dia dengan iblis. Dari sudut yang sama, frase "tidak berbuat dosa" mengacu kepada tindakan berdosa, bukan merujuk kepada keadaan berdosa seperti pada ayat 8 . Sedangkan ayat 8 mengenai frase "tidak berdosa" merujuk kepada sifat dasar, prinsip, atau akar dari dosa, bukan kepada tindakannya. Charles F. Pfeiffer, Everret F. Harrison, The Wycliffe Bible Commentary, 1041.

${ }^{47}$ Perschbacher, Syntax, 49-50.

${ }^{48}$ Anteseden $\alpha$ tós merujuk kepada ó $\theta \varepsilon o ̀ \varsigma$, hal ini juga ditekankan oleh banyak penafsir, walaupun Lieu mengusulkan kemungkinan bahwa rujukannya adalah Yesus jika penyebutan "Anak-Nya" nanti dalam ayat tujuh sebagai penambahan secara redaksional; tetapi, hal ini tampaknya sangat tidak mungkin. Judith M. Lieu, I, II, \& III John ( Louis ville: Westminster John Knox, 2008), 54-55.

${ }^{49}$ Marshall, Epistles, 111. Band. 1 Tim. 6:15-16, Maz. 104:2. 
berjalan di dalam terang. Dengan menggunakan ungkapan tersebut, Yohanes menekankan suatu aspek bagi keseluruhan kehidupan orang percaya, yang dicirikan oleh kualitas dengan terang itu sendiri, serta dijelaskan secara jelas dalam kualitas Allah sendiri. $^{50}$ Oleh sebab itu, bisa disimpulkan bahwa Rasul Yohanes menarik "sebuah hubungan antara karakter Allah dan perilaku orang percaya."

Seseorang mungkin menarik kesimpulan dari hubungan ayat-ayat ini bahwa agar seseorang dapat berjalan di bawah terang, orang tersebut harus bebas dari dosa, karena Allah terbebas dari dosa. Namun ayat 8 menghilangkan gagasan ini, karena Yohanes mengambil topik tentang dosa dari penyebutannya pada akhir dari ayat 7 . Dengan demikian, ayat 9 juga menjelaskan bagaimana seseorang dapat berjalan di bawah Terang Allah di saat ia juga berdosa. Hal ini bukan merujuk untuk menyembunyikan dosa seseorang, namun seperti situasi dalam ayat 8 yang menjelaskan bahwa seseorang harus secara terbuka mengakui saat dosa itu terjadi padanya. Memang, pengakuan dosa dapat dianggap sebagai "tanda pembeda" bagi kumpulan/komunitas orang-orang percaya. ${ }^{51}$ Dosa tidak menghancurkan hubungannya antara Allah dan orang-orang yang berjalan di bawah terangnya, karena orang tersebut sudah diberikan jaminannya secara status di dalam Kristus; namun dibalik itu, orang-orang percaya perlu mengakui dosa-dosa mereka, dan berbalik kepada kumpulan orang-orang percaya daripada menyangkalnya. ${ }^{52}$ Hal ini memberikan informasi bahwa pembersihan dan pengampunan Allah tersedia dengan berlimpah di bawah "terang" itu.

\section{Berjalan di dalam Terang hanya terjadi atas dasar penyucian dan kematian Yesus Kristus}

Yohanes menunjukkan bahwa berjalan di bawah terang berarti "mengalami persekutuan satu sama lain" (1 Yohanes 1:7). Persekutuan dengan Tuhan dan persekutuan dengan orang lain yang mengalami persekutuan dengan Tuhan sudah terbentuk dalam ayat 3, dengan keinginannya untuk memberi kepercayaan kepada pembacanya bahwa mereka sebenarnya hidup dalam Tuhan. Yohanes mengalihkan perhatiannya pada pengalaman mereka tentang persekutuan dengan orang percaya lainnya dan mencatat bahwa pengalaman sejati dapat ditunjukan dengan rasa hormat kepada Tuhan yang terhubung dengan orientasi/arah hidup mereka kepada Tuhan. Oleh sebab itu, 1 Yohanes terus menunjukkan bahwa perjalanan orang-orang percaya yang terus berjalan di bawah terang akan selalu bergantung pada kematian Yesus yang

\footnotetext{
${ }^{50}$ Culy, I, II, III John, 16.

${ }^{51}$ Richard B. Hays, The Moral Vision of the New Testament: A Contemporary Introduction to New Testament Ethics (New York: HarperCollins, 1996), 155.

52 Sangat menarik bahwa baik Injil Yohanes maupun surat-suratnya memberikan istilah bertobat/pertobatan. Mungkin Yohanes menganggap hubungan yang erat antara pengakuan dosa seseorang dan berpaling dari dosa itu. Amsal 28:13 memberikan hubungan ini secara eksplisit. John R.W. Stott, The Letters of John (Illinois.: InterVarsity, 1988), 83.
} 
"membersihkan kita dari segala dosa." ${ }^{53}$ Dalam hal ini, Yohanes menganggap bahwa kematian Yesus sebagai korban yang memberikan pembersihan bagi orang-orang berdosa seperti halnya pengorbanan yang ditawarkan pada Hari Raya Pendamaian (Im 16:30). Dalam 1 Yohanes 1:9, pembersihan dipandang sebagai hasil pengakuan dosa, yang juga mencerminkan juga Hari Pendamaian (Im 16:21). ${ }^{54}$ Tampaknya Yohanes membayangkan pembersihan "setiap dosa" atau "setiap tindakan yang tidak benar" sebagai "sarana anugerah Allah yang terus-menerus" yang diterapkan bagi seseorang yang hidup di dalam terang Allah, entah kapanpun dosa itu dapat terjadi. ${ }^{55}$

Penyucian terus-menerus ini penting bagi mereka yang berjalan dalam terang, dan kematian Yesus telah menyediakan pengorbanan Hari raya Pendamaian bagi umatNya untuk memastikan agar persekutuan denganNya tidak terpatahkan. ${ }^{56}$ Hal ini mungkin mencerminkan ajaran Yesus yang tercatat dalam Yohanes 13, ketika Dia menunjukkan bahwa para murid sudah "bersih," namun mereka tetap harus membersihkan kaki mereka; sama seperti, orang percaya yang hidup di dalam terang Allah dan mengalami persekutuan dengan Allah, namun dari sisi yang lain mereka masih melakukan dosa, tetapi karena kematian dan pengorbanan Yesus, mereka mengalami pembersihan yang rutin dari dosa-dosa mereka. ${ }^{57}$

\section{Hubungan Antara Pengakuan dan Pengampunan Dosa}

1 Yohanes 1: 9 menjelaskan tentang kesetiaan dan keadilan Allah untuk memberikan suatu pengampunan bagi orang-orang yang mengakui dosa-dosanya. Ayat tersebut berdiri sebagai pokok utama dari paragraf ini dengan memberikan suatu implikasi yang utama bagi orang-orang percaya yaitu "Allah adalah terang." Bertentangan dengan situasi yang dinampakan dalam ayat 8, Yohanes mempertimbangkan situasi seseorang yang mengakui dosa yang dipandang sebagai "refleksi dari orang Kristen," setiap kali orang Kristen berbuat dosa. ${ }^{58}$ Bagaimanapun juga kalimat bersyarat pada bagian ketiga ini memiliki konstruksi yang tak terduga dalam eksposisi ini. Kesimpulan dari kalimat bersyarat ini ingin menyatakan bahwa hal-hal yang nyata atau peristiwa-peristiwa tertentu selalu bergantung pada terjadinya situasi yang dinampakan pada kajian dari 1 Yohanes 1:9. ${ }^{59}$ Apodosis (kesimpulan dari kalimat bersyarat) dalam 1 Yohanes 1: 9, "Dia adalah setia dan adil untuk mengampuni dosa-dosa

${ }^{53}$ Culy, I, II, III John, 16.

${ }^{54}$ Frank Thielman, Theology of the New Testament: A Canonical and Synthetic Approach (Grand Rapids: Zondervan, 2005), 550.

${ }^{55}$ George Smeaton, The Doctrine of the Atonement, As Taught by the Apostles (Edinburgh: T\&T Clark, 1870), 450.

\footnotetext{
${ }^{56}$ D. Moody Smith, First, Second, and Third John. (Louis ville: John Knox, 1991), 43-44.

57 Andreas J. Köstenberger, Encountering John, 165.

${ }^{58}$ Gary M. Burge, Letters of John (NIVAC; Grand Rapids: Zondervan, 1998), 82.

${ }^{59}$ Wallace, Grammar, 682.
} 
kita dan untuk menyucikan kita dari segala kejahatan" tidak tergantung apakah kita mengakui dosa-dosa kita. Mungkin saja pernyataan Burton memberikan penjelasan yang terbaik, bahwa "Kesimpulan dari kalimat bersyarat ini dapat dihilangkan, karena ia dapat berdiri di tempatnya untuk menjadi alasan terhadap kalimat bersyarat yang tidak terekspresikan." 60 Dalam konstruksi ini, kata kerja infinitif menyarankan apodosis yang sebenarnya; Oleh karena itu, penulis juga menyarankan untuk menerjemahkan 1 Yohanes 1: 9, "Jika kita mengakui dosa-dosa kita, Ia akan mengampuni dosa-dosa kita dan menyucikan kita dari segala kesalahan, karena Ia setia dan adil untuk melakukannya."

Yohanes mungkin saja menggunakan konstruksi ini untuk menekankan pentingnya karakter Allah dalam mengampuni dosa orang-orang percaya. Kesetiaan dan keadilan Allah juga dijelaskan dalam Perjanjian Lama, yang menghubungkan kesetiaanNya dengan perjanjian kepada umat Israel. Hal ini digambarkan seperti Yeremia 31:34 dan Yehezkiel 36:25, Yohanes tentunya mengakui janji Allah untuk mengampuni dosa dan membersihkan umat-Nya dalam Perjanjian Baru sebagaimana yang digenapi dalam kematian Yesus. ${ }^{61}$ Perjanjian Lama mengajukan pertanyaan bagaimana Allah dapat mengampuni dosa sementara Keadilan Allah juga ditegakan. Yohanes membuat hubungan antara pengampunan dosa dan kematian pengorbanan Yesus dalam 1 Yohanes 2: 1-2 dan 2:12 serupa dengan Paulus dalam Roma 3:21-26. ${ }^{62}$

Mengingat pernyataan Yohanes dalam 2:12 bahwa orang-orang percaya telah diampuni dari segala dosa mereka, kebutuhan untuk pengakuan dosa agar menerima pengampunan dan pembersihan dalam 1:9 menciptakan sedikit permasalahan. Banyak yang mengatakan bahwa Yohanes berbicara tentang dua jenis pengampunan: pengampunan yudisial (atau pembenaran) dalam 2:12 dan pengampunan dosa secara turun-temurun dalam ayat $9 .{ }^{63}$ Mungkin lebih dekat dengan kerangka berpikir eskatologi Yohanes bahwa adanya pembenaran, dimana semua dosa orang percaya diampuni sepenuhnya atas dasar pribadi dan pekerjaan Yesus, sementara ayat 9 menginstruksikan supaya orang-orang percaya memanfaatkan pembenaran yang disediakan olehNya. ${ }^{64}$ Oleh karena itu, mereka yang hidup di dalam terang Tuhan, mengalami persekutuan dengan Tuhan dan orang percaya lainnya harus mengenali sifat-sifatnya dan mengakui dosa-dosa mereka sendiri, serta memiliki kepercayaan penuh karena kematian pengorbanan Yesus dan kesetiaan serta keadilan Allah, sehingga Allah akan selalu mengampuni dan membersihkan dosa-dosa orang percaya. ${ }^{65}$

${ }^{60}$ Ernest De Witt Burton, Syntax of the Moods and Tenses in New Testament Greek (3d ed.; Edinburgh: T\&T Clark, 1898), 108.

${ }^{61}$ Bass, Assurance, 75.

62 Ibid, 76.

${ }^{63}$ Robert A. Morey, The Encyclopedia of Practical Christianity (Las Vegas: Christian Scholars, 2004), 179.

${ }^{64}$ Fraser Watts and Liz Gulliford, Forgiveness in Context: Theology and Psychology in Creative Dialogue (London: T\&T Clark, 2004), 39-40.

${ }^{65}$ Stephen S. Smalley, 1, 2, 3 John (WBC 51; Dallas: Word, 1984), 30. 


\section{Kesimpulan}

Dalam hal memberi penejelasan kepada pembacanya yaitu jemaat yang berada di Asia Kecil tentang kepastian kepemilikan mereka akan kehidupan yang kekal, Yohanes membuka suratnya dengan sebuah ringkasan Teosentris dari pesan dalam Yohanes 1:5 "Tuhan itu terang, dan sama sekali tidak ada kegelapan di dalam Dia." Dari pernyataan teologis ini, menurut Penulis, Yohanes menarik beberapa implikasi tentang realitas kehidupan orang percaya dengan Allah, terutama yang berkaitan dengan pertobatan mereka yang terus-menerus berlanjut. Hanya orang-orang yang benar-benar menjalani kehidupan mereka yang berorientasi pada kebenaran Allah dapat mengklaim dan mengalami persekutuan dengan Allah ini. Mereka yang hidup dengan cara ini dapat mengetahui bahwa mereka juga mengalami persekutuan sejati dengan semua orang percaya lainnya dan mengalami pembersihan setiap dosa yang mereka lakukan secara teratur. Mereka yang menolak kesalahan mereka karena dosa-dosa tersebut, mereka akan selalu ditipu dan sama sekali tidak memiliki pembenaran dari Tuhan. Sebaliknya, orangorang yang mengakui dosa-dosa mereka menerima pengampunan dan pembersihan atas dosa-dosa mereka secara terus menerus, mereka menerima kesetiaan Allah atas perjanjian dan keadilanNya dalam menghukum dosa-dosanya di dalam kematian Yesus. Oleh sebab itu, orang-orang yang menyangkal kesalahan dosa mereka, mereka sebenarnya tidak melakukan dosa setelah menjadi orang percaya, mereka menjadikan Allah sebagai pembohong, padahal Yohanes telah mengatakan secara konsisten bahwa semua manusia berdosa dan bersalah atas dosa-dosa mereka; Oleh karena itu, firman Tuhan tidak akan berdampak pada orang-orang seperti itu.

1 Yohanes 1:5-10 harus memegang tempat yang sangat penting dalam kehidupan orang-orang percaya. Di sini, Yohanes mengajarkan kepada penulis dan pembaca bahwa orang-orang percaya memiliki keyakinan besar bahwa mereka benarbenar terhubung dengan Tuhan pada saat menjalani kehidupannya dan mengevaluasi perbuatannya. Allah menjaga setiap orang percaya dari paradigma keliru bahwa dosa sama sekali tidak berpengaruh pada orang percaya. Sebaliknya, ketika orang percaya telah melakukan dosa, kumpulan orang-orang percaya tidak boleh mencoba untuk menolak mereka di hadapan Allah; Sebaliknya, kumpulan orang-orang percaya tersebut juga harus mengakui tindakan dosa-dosanya yang bertentangan dengan sifat orang-orang percaya sebagai anak-anak Allah (lih 1 Yohanes 3: 4-10), bertobat, dan tahu bahwa orang percaya menerima banyak manfaat dari pengampunan dan pembersihan yang telah diberikan oleh Yesus dalam kematianNya bagi orang-orang percaya. 


\section{DAFTAR PUSTAKA}

Akin, Daniel L. 1, 2, 3 John. New American Commentary 38. Nashville: Broadman \& Holman, 2001.

Bass, Christopher D. That You May Know: Assurance of Salvation in 1 John. NAC Studies in Bible \& Theology 5. Nashville: B\&H, 2008.

Bauckham, Richard. Jesus and the Eyewitnesses: The Gospels as Eyewitness Testimony. Grand Rapids: Eerdmans, 2006.

Baylis, Charles P. 'The Meaning of Walking 'in the Darkness' (1 John 1:6).” Bibliotheca Sacra 149:594 (Apr 1992): 214-22.

Brooke, Alan England. A Critical and Exegetical Commentary on the Johannine Epistles. International Critical Commentary. New York: Scribner's Sons, 1912.

Brown, Raymond E. The Epistles of John. Anchor Yale Bible 30. Garden City: Doubleday, 1982. Repr., New Haven, Conn.: Yale University Press, 2008.

Burge, Gary M. Letters of John. New International Version Application Commentary. Grand Rapids: Zondervan, 1998.

Burton, Ernest De Witt. Syntax of the Moods and Tenses in New Testament Greek.3d ed. Edinburgh: T\&T Clark, 1898.

Carson, D.A. The Gospel According to John. Pillar New Testament Commentary. Grand Rapids: Eerdmans, 1991.

Combs, William W. "The Meaning of Fellowship in 1 John." Detroit Baptist Seminary Journal 13 (2008): 3-16.

Culy, Martin M. I, II, III John: A Handbook on the Greek Text. Waco, Tex.: Baylor University Press, 2004.

DeSilva, David A. An Introduction to the New Testament: Contexts, Methods and Ministry Formation. Downers Grove, Ill.: InterVarsity, 2004.

Hays, Richard B. The Moral Vision of the New Testament: A Contemporary Introduction to New Testament Ethics. New York: HarperCollins, 1996.

Kittel, Gerhard, and Gerhard Friedrich, eds. Theological Dictionary of the New Testament. Translated by Geoffrey W. Bromiley. 10 vols. Grand Rapids: Eerdmans, 1964-1976. 
Köstenberger, Andreas J. A Theology of John's Gospel and Letters: The Word, the Christ, the Son of God. Biblical Theology of the New Testament. Grand Rapids: Zondervan, 2009.

Encountering John: Injil dalam Perspektif Sejarah, Sastra dan Teologis. Malang:S AAT, 2015.

Ladd, George Eldon. A Theology of the New Testament. Rev. ed. Grand Rapids: Eerdmans, 1993.

Lieu, Judith M. I, II, \& III John: A Commentary. The New Testament Library. Louisville: Westminster John Knox, 2008.

Louw, Johannes P., and Eugene Albert Nida. Greek-English Lexicon of the New Testament: Based on Semantic Domains. 2d ed. New York: United Bible Societies, 1996.

Marshall, I. Howard. The Epistles of John. The New International Commentary on the New Testament. Grand Rapids: Eerdmans, 1978.

Maryono, Petrus. Analisis Retoris: Suatu Teknik Studi Hermeneutik terhadap Teks Alkitab. Yogyakarta: ANDI, 2016.

Matera, Frank J. New Testament Theology: Exploring Diversity and Unity. Louisville: Westminster John Knox, 2007.

Morey, Robert A. The Encyclopedia of Practical Christianity. Las Vegas: Christian Scholars, 2004.

Morris, Leon Teologi Perjanjian Baru. Malang:Gandum Mas, 2014.

Newman, Carey C. "God." Dictionary of the Later New Testament and Its Developments. Edited by Ralph P. Martin and Peter H. Davids. electronic ed. Downers Grove, IIl.: InterVarsity, 2000.

Perschbacher, Wesley J. New Testament Greek Syntax: An Illustrated Manual. Chicago: Moody, 1995.

Pfeiffer, Charles F, Everret F. Harrison, The Wycliffe Bible Commentary. Malang: Gandum Mas, 2001.

Porter, Stanley E. Idioms of the Greek New Testament.2d ed. Sheffield: JSOT, 1999.

Runge, Steven E. A Discourse Grammar of the Greek New Testament: A Practical Introduction for Teaching and Exegesis. Bellingham, Wash.: Logos Research Systems, Inc., 2010. 
Schreiner, Thomas R. New Testament Theology. Yogyakarta: ANDI, 2015.

Smalley, Stephen S. 1, 2, 3 John. Word Biblical Commentary 51. Dallas: Word, 1984.

Smeaton, George. The Doctrine of the Atonement, As Taught by the Apostles. Edinburgh: T\&T Clark, 1870.

Smith, D. Moody. First, Second, and Third John. Interpretation. Louisville: John Knox, 1991.

Stott, John R.W. The Letters of John. Tyndale New Testament Commentaries 19. Downers Grove, Ill.: InterVarsity, 1988.

Stuart, Douglas dan Gordon D. Fee, How to Read the Bible for All Its Worth. Grand Rapids: Zondervan, 1993.

Tenney, Merril C. Survey Perjanjian Baru. Malang: Gandum Mas, 2000.

Thielman, Frank. Theology of the New Testament: A Canonical and Synthetic Approach. Grand Rapids: Zondervan, 2005.

Turner, Nigel. Grammatical Insights into the New Testament. Edinburgh: T\&T Clark, 1966.

Wallace, Daniel B. Greek Grammar Beyond the Basics: Exegetical Syntax of the New Testament. Grand Rapids: Zondervan, 1996.

Watts, Fraser and Liz Gulliford. Forgiveness in Context: Theology and Psychology in Creative Dialogue. London: T\&T Clark, 2004.

Westcott, B.F. Epistles of Saint John. Classic Commentaries on the Greek New Testament. $4^{\text {th }}$ ed. New York: Macmillan, 1902.

Witherington, Ben III. Letters and Homilies for Hellenized Christians Volume 1: A SocioRhetorical Commentary on Titus, 1-2 Timothy and 1-3 John. Downers Grove, Ill.: InterVarsity, 2006.

Yarbrough, Robert W. 1-3 John. Baker Exegetical Commentary on the New Testament. Grand Rapids: Baker, 2008.

,"1 John." Pages 176-209 in Zondervan Illustrated Bible Backgrounds Commentary (New Testament) Volume 4: Hebrews to Revelation. Edited by Clinton E. Arnold. Grand Rapids: Zondervan, 2002. 
"2 John." Pages 212-19 in Zondervan Illustrated Bible Backgrounds Commentary (New Testament) Volume 4: Hebrews to Revelation. Edited by Clinton E. Arnold. Grand Rapids: Zondervan, 2002.

Zuck, Roy B. Darrel Bock, A Biblical Theology of The New Testament. Malang: Gandum Mas. 